\title{
COGNIÇÃO EXAURIENTE E SUMÁRIA: SEGURANÇA VERSUS EFETIVIDADE*
}

\author{
André de Albuquerque Cavalcanti Abudd \\ Aluno do Curso de Graduação da Faculdade de \\ Direito da Universidade de São Paulo
}

\begin{abstract}
Resumo:
O presente estudo trata do conflito estabelecido entre os princípios da segurança jurídica e da efetividade, sempre que se ache diante da opção entre modalidades de procedimentos fundados em cognição exauriente e cognição sumária. A tensão entre princípios exige harmonização, sem que se opte pela aplicação de um em desprezo ao outro. Nessa tarefa, o operador do direito conta com as balizas impostas pelo legislador, bem como com regras de calibração presentes no sistema.
\end{abstract}

\begin{abstract}
:
The present study treats about the conflict between the principles of juridical safety and effectiveness that arises from the choice of the procedures based in exhaustive or summary cognition. The tension between those two principles demands harmonization, without the possibility to choose one of them over the other. In this task, the law operator counts on the guidelines imposed by the legislation, as well as the "calibration rules" presented in the system.
\end{abstract}

Unitermos: cognição exauriente e sumária; segurança e efetividade; conflito entre princípios.

\begin{abstract}
"À boa técnica processual incumbe o estabelecimento do desejado racional e justo equilibrio entre as duas exigências opostas, para que não se comprometa a qualidade do resultado da jurisdição por falta de conhecimento suficiente, nem se neutralize a eficácia social dos resultados bem concebidos, por inoportunidade decorrente da demora" (CÂndido Rangel Dinamarco, $A$ instrumentalidade do processo, p. 232)
\end{abstract}

* Monografia vencedora do Prêmio Departamento de Direito Processual, da Faculdade de Direito da Universidade de São Paulo, no ano de 2001, quando o autor cursava o quarto ano da graduação. 
A cognição e a tutela jurisdicional diferenciada

Constitui truísmo, hoje em dia, apontar a efetividade do processo como sintese das preocupações metodológicas dos seus operadores. Essa busca tem raízes na própria natureza instrumental do processo civil moderno, que procura, na clássica expressão de Chiovenda, proporcionar a quem tenha razão, até o limite do praticamente possîvel, "tuḍo aquilo e precisamente aquilo que ele tem direito de conseguir" ।

O processo só terá cumprido sua função instrumental, portanto, na medida em que seja apto a conceder uma tutela adequada e efetiva, isto é, aquela que permita uma aproximação máxima entre o direito subjetivo concedido no plano do direito material e o seu reconhecimento em sede processual, culminando com a concreta oferta do bem ou sịtuação jurídica ao titular da pretensão. ${ }^{2-3}$

Dentre os inûmeros mecanismos adotados pelo sistema, ou preconizados pela doutrina, com vistas a atingir esse amplo objetivo de efetividade, sobressaem as tutelas diferenciadas, importante instrumento de ajuste da tutela jurisdicional às peculiaridades inerentes a cada relação de direito material. Essa diferenciação pode ser entendida em dois sentidos diversos, de acordo com Proto Pisani ${ }^{4}$ : um deles abarca aqueles procedimentos de cognição plena e exauriente, modelados de acordo com as particularidades de cada situação substancial controversa; o segundo refere-se às formas típicas de tutela sumária, calcadas em cognição não-exauriente, cujo objetivo é evitar os males que o tempo pode causar sobre o processo e seus resultados.

Emerge a cognição, portanto, em suas diversas modalidades, como técnica central de adaptaçăo do processo às especificidades dos direitos. Este conjunto de atividades intelectuais ${ }^{5}$ pode ser visto em dois planos distintos, um relativo à sua

I. Dell'azione nascente dal contratto preliminare, in Rivista del diritto commerciale, v. 9, parte I, 1911 , p. 110.

2 Este é o problema central da efetividade do processo, na visão de WatanaBE ( a cogniçăo no) processo civil, $2^{2}$ ed., Campinas, Bookseller, 2000, p. 21 ). A síntese da amplitude do tema está na definição de Dinamarco, para quem essa expressão resume a "idéia de que o processo deve ser apto a cumprir integralmente toda a sua função sócio-político-jurídica, atingindo em toda a plenitude todos os seus escopos institucionais" ( $A$ instrumentalidade do processo, $9^{a}$ ed., São Paulo, Malheiros, 2001, p. 270).

$3 \mathrm{Cf}$., sobre o tema da correspondência entre direito material e direito processual, BEDAQUE, Direilo $e$ processo, $2^{\mathrm{a}}$ ed., São Paulo, Malheiros, 2001, passim.

4 Sulla tutela giarisdizionale differenziata, in Rivista di diritto processuale, n. 4, 1979, p. 538.

$5 \mathrm{Na}$ definição de WATANABE, a cognição é "prevalenteınente um ato de inteligência, consistente em considerar, analisar e valorar as alegaçōes e as provas produzidas pelas partes, vale dizer, as questōes de fato e as de direito que são deduzidas no processo e cujo resultado é o alicerce, o fundamento do judicum, do julgamento do objeto litigioso do processo" (Da cognição cit., p. 58). 
extensão (plano horizontal), outro à sua profundidade (plano vertical). Tomada horizontalmente, a cognição pode ser plena ou parcial (limitada), de acordo com os limites autorizados de sua abrangência. Já sob o plano vertical, a cognição pode ser classificada em exauriente ou sumária, em correspondência ao grau de profundidade adotado. São as combinações dessas diversas modalidades de cognição que possibilitam a concepção de processos com procedimentos diferenciados. ${ }^{6}$

Para os fins a que predisposto o presente estudo, interessa mais de perto a classificação da cognição em exauriente e sumária.

De fato, a sumarização da cognição é técnica destinada a garantir o resultado útil do processo, na medida em que permite a concessão de tutelas jurisdicionais com celeridade, fulcradas em juízos de probabilidade e verossimilhança, ${ }^{7}$ nos casos em que a cognição plena se afigura desnecessária, ou até mesmo danosa ao direito a ser tutelado.

Dentre as várias espécies ${ }^{9}$ de tutela sumária, duas vêm assumindo notável destaque no sistema processual: as antecipações de tutela e as medidas cautelares. ${ }^{10}$ Em razão dessa importância, portanto, elas concentrarão as atenções deste trabalho.

O que difere, basicamente, ambas essas modalidades de tutela é o fato de que as primeiras visam a tutelar o próprio direito postulado, influenciando diretamente a vida das pessoas, ao passo que as cautelares pretendem guarnecer os meios exteriores que podem ser úteis ao processo, para o correto exercício da jurisdição. Enquanto as tutelas antecipadas conferem, imediatamente, o bem da vida pretendido a quem

6 Cf. Watanabe, Da cognição cit., pp. 111 e ss.

7 Cf. CalamandRei, Introduzione allo studio sistematico dei provedimenti cautelari, 1936, trad. port. de C. R. A. Bassi, Introduçāo ao estudo sistemático dos procedimentos cautelares, Campinas, Servanda, 2000, p. 99.

8 Manifestando-se sobre o tema, W ATANABE afirma que "em razão da função que cumpre a cognição sumária, mero instrumento para a tutela de um direito, e não para a declaração de sua certeza, o grau máximo de probabilidade é excessivo, inoportuno e inútil ao fiın a que se destina" (Da cognição cit., p. 128).

9 Todas, no dizer de Proto Pisani, objetivando (a) evitar os custos do processo de cognição exauriente quando presumivelmente não há contestação plausível (p. ex., processo monitório); (b) assegurar a efetividade da tutela jurisdicional nas situaçōes, de caráter não exclusivamente patrimonial, que sofreriam prejuízo irreparável diante do decurso do tempo (tutela sumária antecipada, p. ex.); ou (c) evitar o abuso do direito de defesa (p. ex., antecipação da tutela prevista no art. 273, inc. II, do Código de Processo Civil) (La tutela sommaria, in Appunti sulla giustizia civile, Bari, Cacucci, 1982, p. 322 apud CRUz E Tuccı, Ação monitória, São Paulo, Revista dos Tribunais, 1995, p. 15).

$10 \mathrm{Cf}$. Bedaque, Tutela cautelar e tutela antecipada: tutelas sumárias e de urgência (tentativa de sistematizaçăo), São Paulo, Malheiros, 1998. p. 24. 
provavelmente tem razão, as medidas cautelares, apenas em um segundo momento, produzem resultados que afetam a órbita jurídico-material das pessoas."

De todo modo, como acentua Dinamarco, ${ }^{12}$ muito mais decisivos do que as diferenças ${ }^{13}$ entre essas duas espécies, são os laços teleológicos e estruturais que as unem, fazendo-as convergir para um mesmo gênero: o das medidas urgentes. Realmente, ambas têm o objetivo maior de evitar que o decurso do tempo comprometa o resultado da função jurisdicional. ${ }^{14} \mathrm{O}$ reconhecimento dessa natureza comum entre as tutelas cautelar e antecipada ganhou impulso legislativo com o novo $\S 7^{\circ}$, acrescido ao art. 273 do Código de Processo Civil, portador da regra da fungibilidade ${ }^{15}$ entre essas medidas urgentes. ${ }^{16}$

\section{2 - Cognição e efetividade}

A preocupação com os efeitos do tempo sobre o processo constitui apenas um dos aspectos inerentes à problemática da efetividade..$^{17^{-18}}$ Esta, tomada em toda sua abrangência, constitui problema alheio ao presente propósito. ${ }^{19}$

II Cf. Dinamarco, $O$ regime jurídico das medidas urgentes, in $R F$ 356, p. 33.

12 Cf. Dinamarco, ob. cit., p. 33.

$13 \mathrm{Um}$ rol exaustivo das diferenças estruturais entre essas duas medidas pode ser encontrado em ARruda Alvim, Tutela antecipatória - algumas noģöes - contrastes e coincidências em relaçăo às medidas cautelares satisfativas, in WAMBIER (org.), Repertório de doutrina e jurisprudência sobre liminares, São Paulo, Revista dos Tribunais, 1995, p. 42.

14 É ainda Dinamarco quem lembra que o Código de Processo Civil italiano corrobora a natureza precípua comum entre ambos os institutos, ao destinar a norma do artigo 700 às medidas de urgência atípicas (ob. cit., p. 33).

15 Cf. Dinamarco, A reforma da reforma, São Paulo, Malheiros, 2002, p. 91.

16 In verbis: "se o autor, a título de antecipação de tutela, requerer providência de natureza cautelar, poderá o juiz, quando presentes os respectivos pressupostos, deferir a medida cautelar em caráter incidental do processo ajuizado".

17 Para se ter uma idéia da amplitude do tema, cf. Barbosa Moreira, Notas sobre o problema da "efetividade" do processo, in Grinover et al., Estudos de direito processual em homenagem a José Frederico Marques no seu 70 aniversário, São Paulo, Saraiva, 1982, pp. 203-204. Cf. também, do mesmo autor, Tutela sancionatória e tutela preventiva, in Temas de direito processual, $2^{2}$ série, $2^{2}$ ed., São Paulo, Saraiva, 1988, pp. 21-29.

18 CAPPELLETTI considera a duração excessiva do processo apenas um dentre sete óbices genéricos ao acesso efetivo à justiça (em colaboração com GARTH, Access to justice: the worldwide movement to make rights effective. A general report, 1978, trad. port. de E. G. Northfleet, Acesso à justiça, Porto Alegre. Sergio Antonio Fabris, 1988, pp. 15-28).

19 É preciso ter sempre em mente o alerta de Dinamarco, para quem "a temática da efetividade do processo é, na realidade, muito complexa.A quem muito se em penhe nela, desavisadamente, ocorre o 
Não há que se falar em tutela jurisdicional efetiva, se esta estiver desprovida do atributo da tempestividade..$^{20} \mathrm{O}$ decurso do tempo pode trazer graves danos ao litigante que, apesar de ver reconhecido seu direito no plano processual, não chega a perceber os efeitos do provimento concedido em seu favor, seja porque o processo não dispõe mais de meios para produzir um resultado útil, seja porque o próprio direito material já pereceu.

Dinamarco ${ }^{21}$ enuncia três hipóteses em que o extenso lapso temporal pode ser nocivo. A primeira delas é a do processo cujo provimento de mérito só é concedido quando o direito reconhecido já feneceu; a segunda é representada pela tutela que só chega após muito tempo, mediante "muito sofrimento do titular de direitos"; a terceira, por fim, abrange os casos em que o processo perde os meios externos inerentes ao bom exercício da função jurisdicional. Essa função estatal, aliás, fica prejudicada em qualquer das hipóteses acima, uma vez que a tutela por ela outorgada será, respectivamente, inexistente, intempestiva e, em todos os casos, injusta. "Justiça atrasada não é justiça, senão injustiça qualificada e manifesta", advertiu Ru BARBOSA nos albores do século $X X .^{22}$

Nesse sentido, bastante simbólica a expressão de CARNELUTT1, ${ }^{23}$ para quem o tempo é um "inimigo" do processo, "contra o qual o juiz deve lutar sem descanso"

Não há quem negue o caráter pernicioso do tempo no processo, nos casos em que este tem uma duração patológica e excessiva. A espera razoável pela tutela jurisdicional é mesmo corolário do devido processo legal. ${ }^{24}$

O fato é que a própria duração ordinária do processo de conhecimento pode constituir ameaça à plena realização dos direitos. Esse prejuízo costuma ser

risco de perder-se na extensão e enveredar por toda a área do direito processual -, o que certamente diluiria as observações fundamentais no cipoal de tantos institutos e problemas específicos, minando-lhes a utilidade" (A instrumentalidade cit., p. 273).

20 No pitoresco enfoque de CALAMANDREl, as medidas 'cautelares' visam a "impedir que a soberania do Estado, na sua mais alta expressão que é a da justiça, se reduza a uma tardia e inútil expressão verbal, uma vã ostentação de um lento mecanismo, destinado, como os guardas da ópera burlesca, a chegar sempre demasiado tarde" (Introduzione allo studio sistemático dei provedimenti cautelari, 1936, p. 144, apud OvíDı BAPTISTA, A ą̧äo cautelar inominada no direito, brasileiro, Rio de Janeiro, Forense, 1979, p. 104).

$21 O$ regime jurídico cit., p. 32.

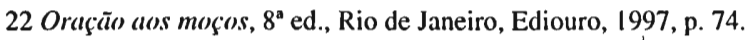

23 Diritto e processo, Napoli, Morano, 1958, n. 232, p. 354.

24 Cf. Cruz e Tuccı, Garantia da prestação jurisdicional sem dilações indevidas como corolário do devido processo legal, in Repro 66, pp. 72 e ss.. 
chamado pela doutrina de dano marginal ${ }^{25}$ representado pelo custo inerente à caminhada processual, provocado àquele que dela precisou para ver satisfeita sua pretensão. Nesses casos, o resultado do processo afasta-se do ideal chiovendiano de que "a necessidade de utilizar-se do processo por quem tem razão não pode reverter em dano a quem dele précisou para obtê-la" ${ }^{20}$

E são muitos os meios de que o sistema lança mão para defender o processo dos males do tempo. A execução provisória, por exemplo, antecipa alguns atos de invasão patrimonial previamente à cristalização dos efeitos da sentença condenatória. A atribuição do caráter de título executivo a certos documentos, de outra parte, permite a supressão de toda a espera inerente ao processo de conhecimento. Com esse fim, ainda, a suspensão da prescrição pela citação válida (CPC, art. 219) e a reestruturação da organização judiciária, com vistas à otimização de seu trabalho. ${ }^{27}$

Dentre eles, no entanto, as formas de cognição sumária aparecem como o instrumento mais incisivo de combate aos malefícios do tempo. ${ }^{28}$ Em certas situações, para que se garanta a efetividade da tutela é necessário que se concedam provimentos baseados em cognição não aprofundada. ${ }^{29}$ Nesses casos, a urgência não se concilia com o tempo necessário à completa produção probatória, ${ }^{310}$ antes da emissão da tutela. ${ }^{31}$

As formalidades inerentes ao processo de conhecimento, seja ordinário

25 A expressão é de Enrico Finzi, in Riv. Dir. Proc. Civ., 1926, n. II, p. 50, apud Calamandrel, Introduzione allo studio cit., p. 37.

26 ChIOVENDA, Istituzioni di diritto processuale civile, v. I, Napoli, Jovene, $2^{n}$ ed., 1935, p. 147 apud CAlAMANDRei, ob. cit., p. 41.

27 Todos os exemplos são de Bedaque, Tutela cautelar e tutela antecipada cit., p. 19, exceto o último, formulado por CARLos Alberto ÁlvARO DE Oliveira, Efetividade e processo cautelar, in Ajuris n. 61, p. 175, e Watanabe, Da cogniçăo cit., p. 144.

28 Carlos Alberto Álvaro de Oliveira chega a atribuir à liminar o caráter de "principal, senāo o único, instrumento do sistema jurídico brasileiro capaz de dar uma solução rápida e expedita para o conflito, em presença da possibilidade de dano à situação material a antes da certeza decorrente da declaração definitiva do Direito" (Efetividade e processo cautelar cit., p. 176). Para THEODORO JÚNIOR, a introdução do instituto da tutela antecipada foi "o maior passo dado pela reforma de nosso direito processual civil em busca do ideal da efetividade da prestação jurisdicional" (O processo civil brasileiro no limiar do novo século, Rio de Janeiro, Forense, 1999, p. 227).

29 Cf. Armelin, Tutela jurisdicional diferenciada, in Repro 65, pp. 50-5I.

30 Cf. Marinoni, Novidades sobre a tutela antecipatória, in Repro 69, p. 105.

31 Daí falar-se na antecipação de atos como "modificazione della disciplina temporale di un determinato procedimento" (TOMMASEO, I provvedimenti d'urgenza - strutura e limiti della tutela anticipatoria, Padova, Cedam, 1983, p. 16). 
ou sumário, ${ }^{32}$ imperativas da busca da certeza quanto à situação controvertida, não se coadunam com aquelas situações que exigem maior celeridade na prestação jurisdicional. ${ }^{33}$ É necessário, então, que o sistema lance mão de medidas protetoras dos direitos, ainda que provisórias.

E essas medidas urgentes, aptas a proteger o resultado do processo, encontram justificativa na garantia constitucional do acesso à justiça (CF, art. $5^{\circ}$. inc. $\mathrm{XXXV).} \mathrm{É} \mathrm{este} \mathrm{dispositivo} \mathrm{que} \mathrm{contém} \mathrm{a} \mathrm{promessa} \mathrm{de} \mathrm{uma} \mathrm{tutela} \mathrm{efetiva,} \mathrm{adequada} \mathrm{e}$ tempestiva, sem a qual nenhuma justiça é obtida. ${ }^{34}$ Realmente, o acesso à ordem jurídica justa ${ }^{35}$ so é conquistado na medida em que as tutelas sejam adaptadas às particulares necessidades de cada relação jurídica. Estando esta ameaçada pelo decurso do tempo, a tutela só será efetiva na medida em que a guarneça. Essa a primordial função da cognição sumária.

\section{Cognição e segurança}

O processo, como síntese de atos realizados mediante progressão (procedimento) e de desenvolvimento da relação entre seus sujeitos (relação processual), ${ }^{36}$ tem necessariamente uma duração.

Isso porque o "processo judiciário, como instrumento de composição da lide (em âmbito extrapenal) ou resolutório de conflitos de interesses de alta relevância social (no campo penal), reclama, em homenagem a um elementar postulado de segurança jurídica, o respeito a uma série de garantias das partes (due process of law), cuja observância se faz incompatível com a precipitação" 37

320 procedimento sumário, apesar do nome, não se funda em cognição sumária. Caracteriza-se "apenas pela abreviação do iter procedimental, em nada interferindo com a cognição". (WATANABE, Da cognição cit., p. 115).

$33 \mathrm{Cf}$. MARINonı, Tutelas diferenciadas e realidade social, in Rodrigues (org.), Liçōes alternativas de direito processual, São Paulo, Acadêmica, 1995, p. 134.

34 A verbalização desses três predicados da tutela jurisdicional deve-se a WATANABE, para quem o "inciso XXXV do art. $5^{\circ}$ não procura assegurar apenas o mero acesso nominal à Justiça, mas sim uın acesso que propicie um tutela efetiva, adequada e tempestiva de direitos" (Tutela antecipada e especifica e obrigaçöes de fazer e não fazer, in Revista especial do Tribunal Regional Federal da $3^{a}$ Região, v. I, 1997, p. 49.

35 Também essa sintética e densa expressão é da lavra de Watanabe.

36 Cf. Cintra, Grinover e Dinamarco, Teoria geral do processo, 15² ed., São Paulo, Malheiros, 1999, pp. 282-283.

37 CrUz E TuCCI, Garantia da prestação jurisdicional cit., pp. 72-73. 
Atento a isso, CARNELUTTI ${ }^{38}$ aponta para o caráter contraditório da idéia de uma justiça rápida e segura: "se la giustizia è sicura non è rapida, se è rapida non è sicura". Alegoricamente, "il seme della verità mette degli anni, perfino dei secoli, per diventare unia spiga (veritas filia temporis)"

A Constituição Federal garante às partes, no processo, a observância do devido processo legal, com todos os corolários a ele inerentes (CF, art. $5^{\circ}$, inc. LIV). Dentre esses, assumem vital relevância o contraditório ${ }^{39}$ e a ampla defesa $a^{40}$ (CF, art. $5^{\circ}$, inc. LV), destinados a impedir toda sorte de surpresas e segredos, inadmissíveis num processo que se pretenda democrático. ${ }^{41}$

O resultado da atividade jurisdicional só terá cumprido fielmente seu objetivo instrumental na medida em que faculte às partes a ampla participação nos seus destinos. A todo momento, devem elas ter a possibilidade de debater as questões envolvidas na causa, podendo reagir às afirmações feitas pela parte contrária. ${ }^{42} \mathrm{O}$ sistema processual deve oferecer aos litigantes, ao longo de todo o procedimento, oportunidades para "participar pedindo, participar alegando e participar provando" 43

Mas não só às partes se endereça o contraditório. $O$ juiz também deve participar ativamente das atividades desenvolvidas no processo, ${ }^{44}$ de modo que tenha o mais intenso contato com os elementos constantes dos autos, indispensáveis à correta formação de seu convencimento. ${ }^{45}$

38 Diritto e processo cit., p. 154.

39 Esta garantia, na completa visão de BARBOSA MOREIRA, "significa, antes de mais nada, que a ambas as partes se hão de conceder iguais oportunidades de pleitear a produção de provas: seria manifestamente inadmissível a estruturação do procedimento por forma tal que qualquer dos litigantes ficasse impossibilitado de subıneter ao juiz a indicação dos ıneios de prova de que pretende valer-se. Significa, a seguir, que não deve haver disparidade de critérios no deferimento ou indeferimento dessas provas pelo órgão judicial. Também significa que as partes terão as mesmas possibilidades de participar dos atos probatórios e de pronunciar-se sobre os seus resultados" ( $O$ princípio do contraditório na atividade de instrução, in RePro 35, p. 232-243).

40 Sobre o tema, v. GrinOvER, O princípio da ampla defesa no processo civil, penal e administrativo, in O processo em sua unidade - II, Rio de Janeiro, Forense, 1984, pp. 56-69.

4 I Cf. Portanova, Princípios do processo civil, Porto Alegre, Livraria do Advogado, 1995, p. 161.

42 Cf. Carlos Alberto Álvaro Oliveira, Garantia do contraditório, in Cruz e Tucci (org.), Garantias constitucionais do processo civil, São Paulo, Revista dos Tribunais, 1999, esp. p. 144.

43 Dinamarco, O princípio do contruditório e sua dupla destinação, in Fundamentos do processo civil moderno, $3^{\mathrm{a}}$ ed., t. I, São Paulo, Malheiros, 2000, p. 125.

44 Essa conduta decorre da moderna perspectiva do ativismo judicial. "A participação que a garantia do contraditório impõe ao juiz consiste em atos de direção, de prova e de diálogo. A lei impõe ao juiz, entre seus deveres fundamentais no processo, o de participar efetivamente" (Dinamarco, ob. cit., p. 131).

45 Cf. BedAque, Tutela cautelar e tutela antecipada cit., p. 86. Cf. também NERY JúNIOR, Princípios do processo civil na constituição federal, 5* ed., São Paulo, Revista dos Tribunais, 1999, pp. 129-130. 
As tutelas calcadas em cognição exauriente e plena, portanto, na medida em que resultam de vasta dilação probatória, bem como de ampla discussão e valoração dos seus resultados, aparecem como instrumento por excelência do princípio da segurança jurídica. De acordo com ele, só se permite a invasão na esfera de direitos do sujeito após ter tido ele franca possibilidade de alegar suas razões, produzindo as provas tendentes a confirmá-las. ${ }^{46}$

4 - O conflito

4.1- Delineamento

Feitas as observações precedentes, salta aos olhos o conflito estabelecido entre a exigência de efetividade, a demandar em alguns casos o recurso às formas de cognição sumária, e a necessidade de segurança, apenas prestigiada por meio de uma cognição exauriente.

$\mathrm{Na}$ condição de expressões que designam princípios, os termos segurança e efetividade são bastante vagos e ambíguos. ${ }^{47}$ Tanto assim é que alguns autores afirmam serem as medidas urgentes imperativo da segurança jurídica do direito ameaçado. ${ }^{48}$ Do mesmo modo, sustenta-se que a observância das garantias do contraditório e da ampla defesa, com ampla dilação probatória, visa à efetividade da tutela jurisdicional, vez que a tutela corresponderá mais proximamente à verdade real. ${ }^{49}$ Como já se notou, o sentido empregado a tais expressões no presente estudo, em correspondência ao tema proposto, é o contrário. A opção por uma ou outra nomenclatura advém de mera convenção. ${ }^{50}$

46 Cf. ZaVASCKI, Antecipação de tutela e colisão de direitos fundamentais, in Wambier (org.), Repertório de doutrina e jurisprudência sobre liminares, São Paulo, Revista dos Tribunais, 1995, p. 85.

47 “Os problemas em torno da ambigüidade diferenciam-se, em parte, das questões sobre a vagueza, pois a incerteza que pretendem indicar refere-se não ao desconhecimento dos objetos ou situaçōes aos quais se pode aplicar o rótulo, mas sim por não possuírem uma clareza paracontextual sobre os diferentes critérios designativos articuláveis ao termo. Em suma, dizemos que um terıno é ambíguo quando temos dúvidas sobre qual a classe a que rótulo se aplica. Especificada a classe, pode surgir a dúvida em torno de sua extensão. Estaremos, entāo, frente a um problema de vagueza" (WARAT, O direito e sua linguagem, $2^{\text {" }}$ ed., Porto Alegre, Sergio Antonio Fabris, 1995, pp. 78-79.

48 Cf. Carlos Alberto Álvaro de Oliveira, Efetividade e processo cautelar cit., p. 177; Carlos Aurélo Mota DE SOUZA, Segurança jurídica e jurisprudência-um enfoque filosófico-jurídico, São Paulo, Letras Trabalhistas, 1996, p. 18.

49 Cf. Barbosa Moreira, Notas sobre o problema da "efetividade" cit., p. 203.

50 "Las dificuldades práticas pueden superarse si tomamos la precaución de precisar, en todos los casos de posible duda, el sentido con que hemos empleado tal o cual palabra o expresión" (CARró, Notas sobre derecho y lenguage, Buenos Aires, Abeledo-Perrot, 1973, p. 28). 
Ambos os valores são extremamente caros ao ordenamento, dada sua natureza constitucional, já apontada alhures. $O$ devido processo legal, de um lado, impõe seja observado, durante todo o curso processual, o pleno contraditório, com as formalidades a ele ligadas, previstas em lei, para que só então o vencido seja privado de seus direitos. De outra parte, o devido processo legal, por meio de seu corolário do acesso à justiça, consubstancia a promessa, feita pelo Estado, de que ao titular de direitos será concedida a respectiva tutela. ${ }^{51-52} \mathrm{E}$ esta, por vezes, deverá adequar-se às necessidades de urgência da relação material, sob pena de nem ser tutela.

Depara o aplicador do direito com duas situações merecedoras de atenção, ambas tendo por eixo comum o fator tempo. De um lado, este é essencial para que o processo seja realizado com todas as suas garantias, em prestígio ao valor da segurança jurídica; de outro, o tempo é o maior inimigo da tutela que precisa ser urgente, diante do risco de perecimento do direito, e portanto de total inefetividade da jurisdição..$^{53}$

Diante de tal antagonismo, tem o operador duas difíceis opções: ou penaliza o autor, impondo-lhe todo o custo do tempo necessário para que o processo chegue ao seu termo, até mesmo correndo o risco de que a tutela se torne ao final inútil; ou confere a determinadas situações medidas tendentes a garantir a efetividade da tutela, atribuindo ao réu o ônus de ter contra si uma decisão cuja correção e justiça são discutíveis. ${ }^{54}$

O conflito entre esses valores exige harmonização, uma vez que ambos são indispensáveis dentro do sistema, e possuem igual peso diante da ordem constitucional. O que não pode ser feito, em hipótese alguma, é optar por um em total desprezo ao outro, ${ }^{55}$ sob pena de dar-se à situação concreta solução inconstitucional. ${ }^{56}$

51 Cf. Cruz e Tucci, Garantia da prestaçäo jurisdicional cit., p. 76.

52 Como se vê, certo está Dinamarco quando afirma que a garantia do devido processo legal “tem o significado sistemático de fechar o círculo das garantias e exigências constitucionais relativas ao processo, numa fórmula sintética destinada a afirmar a indispensabilidade de todas e reafirmar a autoridade de cada uma". (Instituiçōes de direito processual civil, São Paulo, Malheiros, 2001, p. 243).

53 Cf. Zavascki, Antecipação de tutela e colisão cit., p. 87.

54 Cf. Ovído Baptista, A "plenitude de defesa" no processo civil, in Sálvio de Figueiredo Teixeira (org.), As garantias do cidadão na justiça, São Paulo, Saraiva, 1993, p. 155.

55 Cf. Bedaque, Tutela cautelar e tutela antecipada cit., p. 87.

56 Afinal, "el Derecho no quedará justificado sino en la medida en que cumpla las exigencias de tales valores (jurídicos) hasta donde sea humanamente posible" (RECASÉns SICHES, Nueva filosofia de la interpretación del derecho, 2 ed., México, Porrúa, 1973, p. 296). 
A coordenação entre a efetividade e a segurança, como de resto entre quaisquer valores, ${ }^{57}$ demanda, em cada caso, o abrandamento de algum deles em prol do outro. ${ }^{5 x}$ Daí afirmar-se que nenhum valor é absoluto, ${ }^{59}$ dado que sofrem comumente restrições impostas uns aos outros. Essas limitações podem vir escritas na Constituição,"() ou advirem do próprio sistema, sempre que se ache diante da necessidade prática de harmonizar princípios colidentes. ${ }^{\text {(I }}$

Na tentativa de empreender essa conciliação, um dos mecanismos encontrados pelo sistema é a adoção das tutelas provisórias, fundadas em cognição sumária. Protege-se imediatamente a relação ameaçada, diante do risco de ulterior inefetividade do resultado do processo, mas deixa-se a solução definitiva na dependência de uma cognição mais ponderada, baseada em gama maior de elementos.

No entender de CAlAmANDREl, ${ }^{12}$ referindo-se às medidas cautelares, as exigências contrastantes de "celeridade" e "ponderação" estariam conciliadas: "entre o fazer depressa mas mal, e o fazer bem feito mas devagar, os procedimentos cautelares objetivam antes de tudo a celeridade, deixando que o problema do bem e do mal, isto é, da justiça intrínseca do procedimento, seja resolvido sucessivamente com a necessária ponderação nas repousadas formas do processo ordinário"

De fato, as medidas urgentes parecem surgir como técnica de convivência entre os valores da segurança e da efetividade. Por meio delas, o contraditório fíca

57 Sobre o tema, v. Canotıho, Direilo constitucional, 5a ed., Coimbra, Almedina, 1992, pp. $195 \mathrm{e}$ SS., LARENZ, Methodenlehre der rechtswissenschaft, 1991, trad. port. de J. Lamego, Metodologia da ciência do direito, $3^{\mathrm{a}}$ ed., Lisboa, Calouste Gulbenkian, 1997, esp). p. 574 e ss., e Bonavides, Curso de direito constitucional, $4^{\mathbf{a}}$ ed., São Paulo, Malheiros, 1993. p. 251.

58 Nas palavras de LARENZ, "em caso de conflito, se se quiser que a paz jurídica se restabeleça, um ou outro direito (ou um dos bens jurídicos em causa) tem que ceder até um certo ponto perante o outro ou cada um entre si" (Methodenlehe cit., p. 57.5).

59 Barbosa Moreira, manifestando-se sobre o assunto, assinala "que os princípios informativos do processo não são, como tais, absolutos. (...) O princípio do contraditório expressa valores dignos da maior reverência; mas não é pouco freqüente, no direito processual - e no direito tout court - que primeiro o legislador, e depois o intérprete e o aplicador da lei se defrontem com siluações em que a um valor se contrapõe outro também merecedor de tutela, e se vejam na impossibilidade de conciliá-los de tal modo que nenhum deles sofra o mínimo detrimento. Impõe-se, nesses casos, uma op̧̧ão, que há de ser guiada pela regra do 'imal menor'". (A garantia do contraditório cit., p. 238).

60 É o caso, por exemplo, do sigilo das comunicações telefônicas, cuja violação é perınitida coın autorização judicial, para fins de investigação criminal ou instrução processual penal (CF, ant. $5^{\circ}$, inc. XII). Aqui, o interesse público na adequada apuração de um crime sobrepōe-se à esfera de liberdade privada do indivíduo.

61 Exemplo de conflito prático entre princípios é o estabelecido, muitas vezes, entre o direito à privacidade $\mathrm{e} o$ interesse social na vida dos homens públicos.

62 Introduzione allo studio cit., pp. 39-40. 
diferido, não abandonado, ${ }^{6.3}$ para que se atenda a situação de emergência ameaçadora da efetividade. Também a inexistência de coisa julgada material impede a solidificação dos efeitos da decisão, até que se obtenha a necessária segurança sobre a relação controvertida. ${ }^{64}$

Mais do que isso, as tutelas provisórias calcadas em cognição sumária operam a favor do mandamento de igualdade, visto que resgatam a idéia de que o tempo do processo não pode ser um ônus suportado exclusivamente pelo autor. ${ }^{65}$ Não fosse assim, o devido processo legal seria um "privilégio processual" conferido somente ao réu, e negado ao autor, na medida em que este se veria impedido de obter a efetiva realização prática de seus direitos. ${ }^{60}$

Essa foi a orientação que guiou o legislador, na previsão das diversas hipóteses de medidas urgentes típicas. Muitas estão contidas no Livro III do Código de Processo Civil, ${ }^{67}$ assim como em inúmeros procedimentos diferenciados, dentro $^{6 x}$ e fora ${ }^{69}$ do diploma processual, que expressamente prevêem a possibilidade de antecipação da tutela. Mesmo que assim não fosse, o "poder geral de cautela e antecipação" concedido ao juiz autoriza, diante de situação de absoluta urgência, em que o direito afïrmado seja verossímil, a emissão de provimentos sumários não previstos em lei, quer tenham natureza cautelar (CPC, art. 798), quer sejam antecipatórios (CPC, art. 273).

O legislador processual, portanto, pretendeu criar um modelo de solução para o conflito entre segurança e efetividade, prevendo alguns limites dentro dos quais a concessão de medidas urgentes é possibilitada. Foram estabelecidos os mecanismos para a convivência entre esses valores, quando estiverem em rota de colisão. ${ }^{70}$

63 Cf. Marcato, O processo monitório brasileiro, São Paulo, Malheiros, 1998, pp. 30-31.

64 "È una logica conseguenza di queste caratteristiche l'impossibilità di attribuire alla decisione del giudice l'autorità della cosa giudicata" (Liebman, Unitì del procedimento cautelare, in Problemi del processo civile, Milano, Morano, 1962, p. 109).

65 Cf. Marinoni, A antecipação da tutela na reforma do processo civil, São Paulo, Malheiros, 1995, p. 19, para quemn a tutela antecipada é uma "técnica de distribuição do ônus do tempo do processo".

66 Cf. Ovídı Baptista, A "plenitude de defesa" cit., p. 154.

$67 \mathrm{O}$ arresto e o sequiestro, por exemplo.

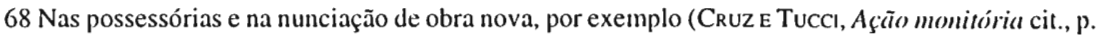
16). Também no processo dos embargos de terceiro, e na demanda para cumprimento específico de obrigações de fazer e não fazer (WaTANABE, Da cognição cit., p. 133).

69 É o caso da ação civil pública, ação popular, ação de desapropriação, mandado de segurança, dentre outros exemplos, tambémn de Watanabe, ob. cit., p. 133.

70 Cf. Zavascki, Antecipaşão da tutela e colisão cit:, pp. 87-88. 
As técnicas previstas pelo legislador, entretanto, operam no plano abstrato, não dando conta, muitas vezes, da multiplicidade de situações postas diante do juiz, no caso concreto, que podem levar a um sem número de relações conflitivas. Outra não é a razão de se atribuir, ao juiz, o "poder geral de cautela ou antecipação" que intenta exatamente aplicar-se às situações não imaginadas pelo legislador, quando da elaboração das medidas típicas. ${ }^{71}$

Ao juiz cabe, portanto, enorme parcela da responsabilidade de encontrar, caso a caso, a solução prática para as exigências antagônicas de segurança e efetividade. ${ }^{72}$

\section{2 - Segurança versus efetividade: critérios de solução}

Não há dúvidas de que os valores da segurança e da efetividade são igualmente caros ao ordenamento. Ambos são acolhidos em sede constitucional, sem qualquer desnível hierárquico, ${ }^{73}$ merecendo igual atenção do operador do direito. ${ }^{74}$

A garantia do acesso à justiça $\left(\mathrm{CF}\right.$, art. $5^{\circ}$, inc. XXXV) contém a solene promessa de que àquele que tiver razão será concedida a tutela apta a proporcionar-lhe o pleno exercício do seu direito (supra, n. 2). E a consecução desse escopo só se torna possível na medida em que as formas de tutela sejam adaptadas às particulares necessidades das relações substanciais. ${ }^{75}$

Por outro lado, o princípio da segurança jurídica, no que condiz com o problema da cognição, ${ }^{76}$ está por trás das garantias do contraditório e da ampla defesa,

71 Cf. ZaVASCKI, ob. cit., pp. 87.

72 “(...) verificados os pressupostos descritos nas regras mencionadas, significa que o conflito entre segurança e efetividade está presente. Cabe ao juiz encontrar a solução mais adequada para solucioná-lo, em conformidade com os parâmetros estabelecidos pelo legislador". (BEDAQUE, Tutela antecipada e tutela cautelar cit., p. 87).

73 A hierarquia potencial, ou "possibilidade de ordenação ou graduação preferencial", é uma das características típicas dos valores, considerados dentro de sociedade deternninada, conforme ensina REALE, Filosofic do direito, v. I, $3^{\mathrm{a}}$ ed., São Paulo, Saraiva, 1962, p. 171.

74 Cf. Zavasckı, Antecipação da tutela e colisão cit., p. 83.

75 "(...) seja em termos de procedimentos de cognição plena e exauriente ajustados às peculiaridades das situações substanciais controvertidas, seja em forma de procedimentos de cognição sumária, que atendain aos reclamos de extrema rapidez na concessão do provimento jurisdicional" (WaTANABE, Da cognição cit., p. 145).

76 Essa restrição é aqui feita em virtude da amplitude da segurança jurídica, enquanto princípio constitucional. É ela que está por trás das garantias da coisa julgada, do ato jurídico perfeito e do díreito adquirido, por exemplo. (Cf. CARlos Aurélo Mota de SouzA, Seguranç̧a jurídica e jurisprudência cit., p76).. 
corolários do devido processo legal (CF, art. $5^{\circ}$, incs. LIV e LV) (supra, n. 3). A todos deve ser concedida a oportunidade de defender-se e demonstrar suas razões no processo, por mais inverossímeis que pareçam ser. Só assim se legitima a invasão na esfera de bens ou direitos do sujeito processual.

As modalidades de tutela fundadas em cognição sumária, como já apontado alhures, emergem como mecanismos tendentes a solucionar a tensão entre ambos esses direitos fundamenlais.

Toda colisão de princípios, para ser resolvida no caso concreto, exige o abrandamento de um em benefício do outro. ${ }^{77}$ Isso não significa que aquele postulado que sofreu prejuízo seja declarado nulo ou sua aplicação seja excepcionada. ${ }^{7 \times-79}$

Ocorre que, tomado o caso concreto, um dos princípios deve ter maior prevalência, da mesma forma que em situação diversa resultado contrário pode ser obtido. ${ }^{80}$ Com isto se quer dizer que em cada relação, concretamente considerada, os princípios têm um peso diferente, e que o de maior quilate deve preponderar. ${ }^{\mathrm{x}}$

$\mathrm{Na}$ tentativa de harmonizar o "momento de tensão" entre princípios, portanto, o operador do direito deve destinar especial atenção às singulares circunstâncias da situação concreta, atribuindo a cada um seu peso particular in casu. ${ }^{82}$

Para JosÉ Afonso dA SILva, seu postulado está por trás das regras de todos os incisos entre o XXXVI e o LXXIII, do art. $5^{\circ}$ da Constituição Federal (Curso de direito constitucional positivo, $18^{a}$ ed., São Paulo, Malheiros, 2000, p. J26). Na relação com os graus de cognição, entretanto, a segurança relaciona-se mais de perto com as garantias do contraditório e da ampla defesa.

77 “Os princípios processuais não são absolutos, até porque não são raras as situações em que a atuação de um deles de certo modo conflita ou parece conflitar com a atuação de outro, de tal maneira que é necessairio compatibiliza-los com o mínimo de sacrificio para ambos, mas às vezes, inevitavelmente, com algum sacrificio (grifos nossos)" (Cf. Barbosa MoreIra, Os princípios do direito processual civil ma comstituifäou de 1988, in Tubenchlak e Bustamante (org.), Livro de estudos jurídicos, v. 4, Rio de Janeiro, Instituto de Estudos Jurídicos, 1992, p. 244).

78 Cf. Bonavides, Curso de direito constitucional cit., p. 251.

79 O princípio abrandado não é eliminado do sistema exatamente porque da incompatibilidade estabelecida entre princípios não resulta unna antinomia jurídica (GraU, A ordem ecomômica na constituisăo de 1988, 6ª ed., São Paulo, Malheiros, 2001, p. 100).

80 Esse é o quadro dos jogos de princípios, no dizer de Grau (ob. cit., p. 200).

81 Essa atividade do intérprete é tornada possível porque "os princípios possueın uma dimensão que as regras não têm - a dimensão do peso ou da importância. Quando os princípios se intercruzam (...), aquele que vai resolver o conflito tem de levar em conta a força relativa de cada um" (Dworkin, Taking rights seriously, 1978, trad. port. de N. Boeira, Levando os direitos a sério, São Paulo, Martins Fontes, 2002, p. 42). Cf. também Alexy, Theorie der Grumdrechte, Baden-Baden, 1985, p. 79, upud Bonavides, Curso de direito constitucional cit., p. 251.

82 Cf. Canotilmo, Direito comstituciomal cit., p. 196. 
Nesse contexto, a doutrina conferiu algumas ferramentas ao exegeta, chamadas princípios de solução, que visam a reduzir ao máximo o prejuízo eventualmente sentido a algum dos pólos colidentes, legitimando a opção pela prevalência do outro. Esquematicamente, tem-se (a) o princípio da necessidade, ${ }^{{ }_{3} .3} \mathrm{de}$ acordo com o qual a limitação a direito fundamental só será viável quando não houver possibilidade, efetivamente, de convivência irrestrita com outros; (b) o princípio da menor restrição possível, ${ }^{84}$ associado ao princípio da proporcionalidade, ${ }^{8,5}$ segundo o qual a limitação a direito fundamental não poderá ir além do estritamente necessário para que se opere a harmonização pretendida; e (c) o princípio da salvaguarda do núcleo essencial, ${ }^{\mathrm{xh}}$ cujo teor inviabiliza a solução que represente eliminação de um dos pólos conflitantes, ou supressão de seu postulado elementar. Este último princípio, aliás, vem positivado no art. 19, (2), da Lei Fundamental da Alemanha. ${ }^{87}$

Impõe-se trazer a questão para o âmbito específico do conflito entre segurança e efetividade, verificado sempre que se ache diante da opção entre uma modalidade de tutela calcada em cognição exauriente e outra sumarizada (urgente).

O legislador, ao prever inúmeras hipóteses para a concessão de medidas urgentes, cuidou de traçar certos limites, dentro dos quais a restrição à segurança jurídica é a menor possível. ${ }^{8 x}$ Criou, assim, um arcabouço teórico tendente a tornar efetivos os ditames dos princípios de solução acima expostos. São as aqui denominadas balizas, que tornam legítima a concessão de provimentos de urgência.

E são várias as contribuições legislativas para a conciliação das exigências contrapostas de segurança e efetividade. ${ }^{x y}$

83 Cf. ZaVASCKı, Antecipaçũo da tutela, São Paulo, Saraiva, 2000, p. 63.

84 Cf. Larenz, Methodenlehre cit., p. 578, apud ZaVASCKı, ob. cit., p. 84.

85 Sobre o tema, cf. SuzANA DE Toledo Barros, $O$ princípio da proporcionalidade e o comtrole de constitucionalidade das leis restritivas de direitos fundamentais, Brasília, Brasília Jurídica, 1996. LARENZ recomenda o emprego desse princípio sempre que "o problema consista em determinar onde se situa o limite da satisfação lícita de um interesse à custa de outro (...) também digno de tutela" (ob. cit., apud ARAgäo, Medidas cautelares inominadas, in Revista brasileira de direito processuul, v. 57, p. 44).

86 Cf. CANotilho, ob. cit., p. 630, apud Zavascki, ob. cit., p. 84.

87 Segundo consta da Lei, "em nenhum caso pode um direito fundamental ser afetado no seu conteúdo essencial" (trad. livre).

88 A definiçāo desses limites passou a ser o problema central das tutelas antecipadas, de acordo com Botelho de MESQuita (Limites ao poder do juiz, nas cautelares antecipatórias, in Revista brasileira de Direito Processual, v. 56, p. 43).

89 Além, é claro, da própria previsão legal da possibilidade de concessão das medidas urgentes, esta mesına o primeiro mecanisıno legislativo de solução do conflito (supra 4.1). 
Em primeiro lugar, tem-se que as medidas urgentes são provisórias ${ }^{30}$ (CPC, arts. $273, \S \S 3^{\circ}$ e $4^{\circ}$ e 807 ). A decisão que as concede tem "reduzido nível de imunidade","' podendo ser revista a qualquer tempo pelo órgão prolator. Seus efeitos têm duração limitada,"2 cujo termo final é outro provimento, de caráter definitivo (sentença), que pode confirmar ou contrariar o quanto foi antes decidido liminarmente."3

Assim, se no curso da instrução processual, operada ulteriormente à concessão da tutela de urgência, o quadro fático-jurídico resultar contrário ao que antes parecia corresponder à verdade, nada obsta a que aquela decisão inicialmente concedida seja reformada.

Na esteira dessa primeira baliza, a execução da medida urgente (de natureza condenatória) seguirá os moldes da execução provisória, com todos os seus limites, ${ }^{44}$ estabelecidos em respeito à inexistência de certeza sobre o direito exeqüendo, o que só se obterá por meio da ulterior cognição exauriente (segurança jurídica).

O segundo requisito é o da excepcionalidade..$^{95}$ De fato, as medidas urgentes são exceção ao sistema de cognição exauriente, vez que destinadas a tutelar aquelas situações que se encontrem diante de perigo concreto, atual e grave, ${ }^{96}$ impositivo de um risco à própria efetividade ulterior da tutela (periculum in mora). Ao mesmo tempo, somente as relações que, por meio de simples cognição superficial ou sumária,

90 Há quem reserve a expressão provisoriedade para as antecipações de tutela, preferindo falar em temporariedade no trato das medidas cautelares (OvíDo BApTISTA, Do processo cautelur, Rio de Janeiro, Forense, 2001 , p. 86 e ss.). A distinção entre as denominações deve-se a CALAMANDREI, para quem "o conceito de provisoriedade é um pouco diferente, e mais restrito, que aquele de temporaneidade. Temporâneo é, simplesmente, aquilo que não dura sempre, aquilo que, independentemente da superveniência de outro evento, teın por si ınesıno duração limitada; provisório é, por sua vez, aquilo que é estabelecido para durar até quando não sobrevenha um evento sucessivo, em vista e na espera do qual o estado de provisoriedade permanece no ínterim" (Introduzione allo studio cit., pp. 25-26).

91 Cf. Dinamarco, A reforma do código de processo civil, $3^{\text {a }}$ ed. São Paulo, Malheiros, 1996, p. 146.

92 Cf. Calamandrei, Introduzione cillo studio cit., esp. p. 25.

93 A doutrina costuma negar o caráter provisório de algumas medidas cautelares (produção antecipada de provas, p. ex.). De todo modo, essa constatação não infirma a provisoriedade como característica predominante em tais provimentos.

94 Exigência de caução, responsabilidade objetiva do exequiente pelos danos derivados do processo executivo, vedação à realização de atos que importem alienação de domínio, etc..

95 "Somente em casos absolutamente excepcionais deve o sistema perınitir a resolução da situaçāo de direito substancial pela via do processo de cognição sumária. Toda vez que isso ocorre, tem-se a amputação de garantias constitucionais da parte contrária, privada do contraditório, da ampla defesa, do devido processo legal, enfim". (Bedaque, Tutela antecipada e tutela cautelar, cit., p. 77).

96 Cf. ZAVASCKı, Antecipaç̧ōo da tutela e colisão cit., p. 91. 
afigurem-se prováveis (no caso das cautelares̄, verossimilhantes), ${ }^{97}$ autorizam a concessão da medida.

O "abuso do direito de defesa" ou o "manifesto intuito protelatório do réu”, ainda, integram o caráter excepcional das medidas urgentes, especificamente no tocante à modalidade prevista no art. 273, inc. II, do Código de Processo Civil. ${ }^{98}$

A terceira baliza legitimadora é a da reversibilidade dos efeitos" da tutela, requisito necessário para que se concedam medidas urgentes (CPC, art. $273, \S$ $2^{\circ}$, a contrario sensu). Da própria inexistência de certeza sobre o direito postulado decorre a necessidade de que, ao menor sinal de contrariedade ao que antes se pensava provável, possa-se reconduzir as coisas ao seu estado anterior. ${ }^{1\left({ }^{1}\right)}$ Fosse de outro modo, os efeitos da tutela "provisória" seriam perenes sobre a esfera de direitos do réu, e eventual equívoco na emissão do provimento não poderia ser retificado.

Como se nota, esse requisito tem estreita ligação com o da provisoriedade.

Se a situação criada pela emissão da tutela pudesse ser irreversível, a decisão que a concedeu seria materialmente definitiva.

Também a responsabilidade objetiva (CPC, art. 811, aplicável analogicamente às antecipações) do requerente da tutela pelos danos causados à outra parte $^{10 !}$ é elemento legitimador de sua concessão. Uma vez que baseadas em cognição sumária, as medidas urgentes trazem em seu bojo um potencial danoso. Realizada a

97 A distinção terminológica entre possibilidade, verossimilhança e probabilidade não é pacífica na doutrina. O sistema brasileiro parece ter adotado a classificação de CALAMANDREI, para quem o juizo de probabilidade (exigido para as antecipaçōes) aproxima-se mais da certeza do que o juízo de verossimilhança (requisito das cautelares) (Diritto processucle civile, trad. port. de L. Abezia e S. D. F. Barbery, Direion Processual Civil, v. III, Campinas, Bookseller, 1999, p. 276).

98 Para uma análise especifica dessa hipótese de medida antecipatória, v. MARINONI, Observasūoues sobre a tutela antecipatória, in Repro 79/104, esp. p. 114 e ss..

99 É Dinamarco queın lembra que "(...) não é da irreversibilidade do proviınento que se cogita. A superveniência da sentença final, ou eventual reconsideração pelo juiz, ou o julgamento de algum agravo, podem reverter o provimento mas nem sempre eliminarão do mundo dos fatos e das relações entre as pessoas os efeitos já produzidos" (A reforma do código de processo cit., p. 148, nota 12). Nessa esteira, Carlos Alberto Álvaro de Oliveira sugere a alteração do texto do art. $273, \$ 2^{\circ}$, para "perigo de irreversibilidade dos efeitos do provimento a ser antecipado" (Comentúrios ao código de processo civil, $3^{\mathrm{a}}$ ed., v. VIII, t. II, Rio de Janeiro, Forense, 1988, n. 3, p. 6).

100 Manifestando-se sobre o tema, ArRuda Alvim atesta que "a reversibilidade é necessária até mesmo pela regra do art. $5^{\circ}, \mathrm{LIV}$, da CF, pois, se irreversível fosse, alguém restaria condenado 'seın o devido processo legal', e, ainda, teria sido esse alguém, privado de seus bens sem o contraditório e ampla defesa 'com os meios e recursos a ela inerentes' (CF, art. $5^{\circ}$, LV)" (Tutela antecipatória cit., p. 30).

10I Sobre o tema, v. Armelin, Responsabilidade objetiva no código de processo civil, in CRuz E Tuccl (org.), Processor civil - evolug̣:ão - 20 cmos de vigência, São Paulo, Saraiva, 1995, pp. 109-116. 
instrução completa e constatado que o que antes parecia improvável corresponde à verdade, nada mais natural que o requerente e beneficiário da tutela provisória arque com os prejuízos daí decorrentes. ${ }^{112}$

A exigência de calıção (CPC, art. 804, também aplicável às antecipações ${ }^{103}$ ), por fïm, é também uma baliza legitimadora. Consiste em "garantia contra os danos que o requerido possa vir a sofrer em virtude da liminar" 1044 Por outro lado, reforça a reversibilidade da medida urgente, que fïca favorecida ou até mesmo assegurada se a caução lor prestada e com isso se puder retornar ao cstado anterior caso o autor não tenha razão afinal. ${ }^{105}$

O rol acima exposto não tem a pretensão de ser exaustivo. O sistema processual dispõe de outros mecanismos que, apesar de desempenharem suas funções perante a generalidade da ordem jurídica, podem ser usados com bastante eficiência para a harmonização do conflito segurança-efetividade.

O melhor exemplo reside no ágil instrumento do mandado de segurança, que confere adaptabilidade ao sistema, na medida em que permite a revisão, pelo tribunal, do provimento liminar do juiz. ${ }^{106}$ Desse modo, eventuais desacertos ou excessos na decisão de primeira instância podem ser desfeitos velozmente pelo órgão judiciário superior. ${ }^{107}$ Resultado semelhante pode ser obtido pela via do agravo de instrumento, com pedido de suspensão dos efeitos da decisão recorrida.

Há situações, contudo, em que a aplicação das balizas não se presta a solucionar convenientemente o choque entre efetividade e segurança. Nesses casos, o conflito de interesses das partes é tão profundo que a opção por um deles implica o

102 Cf. Dinamarco, O regime juridico cit., p. 43.

103 É Dinamarco queın defende a exigência de caução, nas tutelas antecipadas, fora das hipóteses em que a decisão tiver nalureza condenalória (para esses casos há o art. 588, inc. I, do CPC) (ob. cit., p. 44).

104 Galeno lacerda, Comentários ao código de processo civil, $4^{\mathrm{a}}$ ed., v. VIII, t. I, Rio de Janeiro, Forense, 1992, p. 194.

105 Cf. Dinamarco, ob. cit., p. 44.

106 “(...)podendo, a sua vez, este provimento liminar (do mandado de segurança) ser revisto pelo órgão Colegiado na próxima sessão, sujeitando-se a decisão dele emanada ao controle dos Tribunais Superiores, por meio de recurso especial ou extraordinário, acoplando-se-Ihe medida cautelar com pedido de liminar" (Carlos Alberto Álvaro de Oliveira, Efetividade e processo caltelar cit., pp. 178-179).

107 "Faculta-se, destarte, um autêntico contraditório imediato, não apenas o diferido mencionado pela doutrina européia, como também e sobretudo pronto controle por pelo menos duas instâncias sucessivas superiores. Essa circunstância, além de se prestar à fiscalização externa (...) dos interesses contrapostos, reprime os eventuais abusos, adequando o instrumento à sua finalidade essencial". (Carlos AlBerto Álvaro de Oliveira, ob. cit., p. 179). 
total sacrifício do segundo. São os chamados casos extremos, ou limite, em que a salvação de qualquer das pretensões conllitantes provoca, necessariamente, o abandono da outra.

Um bom exemplo é o do poder público que pretende dizimar rebanhos sobre os quais recai forte suspeita de transmitirem doença letal ao homem. Sua intenção encontra resistência nos interesses dos proprietários dos animais. Aqui, a concessão liminar da tutela pedida pelo primeiro compromete definitivamente o direito à segurança jurídica dos demandados. Afinal, uma vez sacrificadas as rezes, já não há razão para se discutir sua viabilidade. De outra parte, o indeferimento da medida pleiteada aniquila a pretensão à efetividade do processo, já que, transmitida a enfermidade, eventual provimento favorável ao poder público seria inútil.

Como se nota, nessas hipóteses os efeitos do provimento judicial tornamse irreversíveis, qualquer que seja seu teor. E isso advém não da vontade do juiz, mas da própria natureza das coisas. ${ }^{108}$ Nesses casos, "o perigo de irreversibilidade dos cfeitos práticos do provimento não pode servir de empeço à concessão da tutela antecipatória urgente" $1(\%)$

Apesar da estranheza que pode causar, à primeira vista, a idéia de um prejuízo irreparável provocado pela tutela urgente, essa é a única solução lógica para esses casos-limite. ${ }^{\prime \prime \prime}$ Não se contraria aqui a anteriormente apontada baliza da reversibilidade, mas essas situações excepcionais reclamam, para a salvaguarda de um direito, a destruição do outro, com ele colidente. A se exigir a reversibilidade, nesses casos, imporia-se sempre o prejuízo definitivo ao autor, sem perquirir sequer da probabilidade de sua pretensão."'

$108 \mathrm{Cf}$. ZaVASCKı, Antecipação da turela e colisĩo cit., p. 101.

109 Marinoni, Novidades sobre a lutela cit., p. 106. Carlos Alberto Álvaro de Oliveira cita, como exemplo de situação potencialmente irreversível, os alimentos provisionais do art. 852, do estatuto processual (Comentírios cit., p. 6).

110 "Nos casos limites, (...) embora o possível efeito danoso ao interesse do demandado, não se configura um emprego abusivo da cautela, se efetivamente presentes os pressupostos indispensáveis ì sua concessão" (Carlos Alberto Álvaro de Oliveira, Efelividude e processó culutelur cit., p. 177).

111 Como bem lembra Lucon, "se a denegação da tutela antecipada puder provocar dano irreparável ou de difícil reparação ao autor, muito superior àquele suportado pelo réu no caso de eventual concessão, a antecipação (...) deve ocorrer. A irreversibilidade deve ser sempre analisada por mais de um ângulo, pois o processo não tem por finalidade tutelar os interesses de apenas um dos sujeitos processuais". (Eficcícia das decisões e execuşāo provisória, São Paulo, Revista dos Tribunais, 2000, pp. 268-269). A esse propósito, já decidiu o Superior Tribunal de Justiça que "a exigência da irreversibilidade (...) não pode ser levada ao extremo, sob pena de o novel instituto da tutela antecipatória (sic) nāo cumprir a excelsa missão a que se destina" (2a Turma, Resp n. 144.656-ES, rel. Min. Adhemar Maciel, j. 6.10.97, DJU 27.10.97). 
A razão para a concessão de medidas urgentes, nessas hipóteses, é fornecida por TOMMASEO:"12 "se non vi è altro modo per evitare un pregiudizio irreparabile a un diritto soggetivo che appaia probabile, si deve ammettere che il giudice possa provocare un prejudizio anche irreparabile al diritto che gli paia improbabile".

A opção do julgador, portanto, tende a favorecer aquele direito que se assemelha provável, em detrimento completo daquele que parece inverossímil. E isso só se justifica ante a necessidade irretorquível de se optar por um deles apenas.

Novamente cabível a observação de Tommaseo, ${ }^{113}$ que de tão expressiva não pode ser parafraseada: “(...) il legislatore preferisce sia evitato um pregiudizio irreparabile a un diritto la cui esistenza appaia probabile anche al prezzo di provocare un danno irreversibile a un diritto che, in sede di concessione della misura cautelare, appaia invece improbabile: in altri termini, il diritto probabile prevale sul diritto improbabile" (grifos nossos).

Essa difícil escolha, cabível ao juiz da causa, requer deste um exame bastante ponderado dos interesses periclitantes. ${ }^{114}$ São redobrados o fardo e a responsabilidade de dar a palavra final sobre o conflito efetividade-segurança, nesses casos em que o provimento judicial, baseado apenas em cognição sumária, produzirá efeitos irreversíveis sobre a esfera de direitos de um dos indivíduos.

Nessa tarefa, novamente dispõe o aplicador de mecanismos objetivos úteis. Deve o juiz valer-se de certas regras, que não compõem o ordenamento jurídicopositivo, mas integram o sistema (regras estruturais), ajustando-o conforme as necessidades do caso. Utilizando-nos da nomenclatura de FERRAZ JúNIOR, ${ }^{115}$ são regras de calibração ou de ajustamento do sistema.

A primeira dessas regras é o juízo do mal maior, cuja formulação se

112 Intervento no "Colloquio Internazionale", in Les mesures provisoires en procédure civile, Milano, Giuffrè, 1985, p. 307, apud MARINONI, Tutela cautelar e tutela antecipatória, São Paulo, Revista dos Tribunais, 1992, p. 126.

113 I provvedimenti d'urgenza cit., p. 155 apud MARINONI, Tutela cautelar e tutela antecipatória, ob. cit., p. 126.

114 "Caberá ao juiz, com redobrada prudência, ponderar adequadamente os bens e valores colidentes e tomar a decisão em favor dos que, em cada caso, puderem ser considerados prevalentes à luz do direito. A decisão que tomar, em tais circunstâncias, é ınais que antecipação provisória; é concessão ou denegação da tutela em caráter definitivo" (ZAVASCKI, Antecipaşão da lutela e colisão cit., pp. 101-102).

115 Introdução ao estudo do direito - técnica, decisão, dominação, São Paulo, Atlas, 1994, esp. p. 190. 
deve a DinAmARCo. ${ }^{116-117}$ O juiz deve apreciar, em perspectiva, os males produzidos ao pleiteante da medida, caso a tutela seja denegada, assim como os males acarretados à outra parte, na hipótese de concessão. Esse raciocínio deve considerar, ainda, a probabilidade da ocorrência do dano para cada um dos lados, para aferir onde estão os maiores riscos (juizo do mal mais provável). ${ }^{118}$ Aliam-se o juízo do mal maior e do mais provável ao juizo do direito mais forte, ${ }^{(1)}$ por meio do qual é posto em contraste o peso jurídico representado pelas pretensões de uma e de outra parte.

Dessa forma, a solução a ser encontrada pelo julgador deve tender a evitar, a todo custo, prejuízo irremediável ao interesse que the pareça mais valoroso, levando-se em conta, sempre, o grau de probabilidade dos direitos em jogo.

Um exemplo torna fácil a demonstração da utilidade que possuem esses juízos, ante um conflito que exija o sacrifício de um dos interesses envolvidos. É o do beneficiário de um contrato de seguro-saúde que, diante da recusa da empresaseguradora em custear um tratamento médico necessário à manutenção de sua vida, pretende seja ela compelida a tanto, por meio de uma liminar. A companhia, a seu turno, alega que os efeitos da tutela concedida em favor do segurado seriam irreversíveis, frente à pobreza crônica deste, impeditiva da devolução do valor pago. Entre o efeito irreversível que a antecipação da tutela provocaria sobre o patrimônio da empresa, e a conseqüência igualmente irreversível que a denegação da medida traria à vida do segurado, a opção deve tender, obviamente, a preservar este último interesse.

É claro que as regras de calibração permeiam a atividade jurisdicional em qualquer hipótese em que se ache diante do conflito segurança-efetividade, e não só nos casos-limite. ${ }^{120}$ Isso porque tratando-se de cognição sumária, e portanto de juízo de probabilidade, sempre há um risco ${ }^{121}$ inerente à função do juiz. Ocorre, todavia,

116 O regime juridico cit., p. 35 .

117 No direito português, como anota Lucon, há uına regra consubstanciadora do juízo do mal maior, segundo a qual "a providência pode, não obstante, ser recusada pelo tribunal, quando o prejuízo resultante para o requerido exceda consideravelinente o dano que coin ela o requerente pretende evitar" (Código de Processo Civil, art. 387, n. 2 apud Eficcícia das decisões cit., p. 268).

118 Cf. LuCon, ob. cit., p. 269.

119 Cf. Dinamarco, ob. cit., p. 35.

120 Afinal, "é evidente que, mesmo observando estes princípios (os princípios de solução elencados no início deste item), fica ainda uma margem muito ampla para uma valoração judicial pessoal" (LARENZ, Methodenlehre cit., p. 586). É sobre esse espaço interpretativo que atuam as regras de calibração.

121 "O risco assumido (...) reside na hipótese de, produzido o restante da prova, (...) vir o juiz a constatar que aquilo que entendera verossímil, na realidade, total ou parcialmente, não traduzia a real situação, que veio a revelar diferente, ulteriormente" (ARRUda Alvim, Tutela antecipatória cit., p. 38). “(...) esses riscos hão de ser calculadamente aceitos, desde que constituam o custo aceitável de outras vantagens certas" (Dinamarco, $A$ instrumentalidade cit., p. 251). 
que seu uso assume vital importância para a resolução dos chamados casos extremos, acima apontados, dada sua especial gravidade sobre a órbita jurídica dos sujeitos processuais. ${ }^{122}$

O sistema, portanto, dispõe de uma série de mecanismos, postos ao alcance do aplicador do direito, aptos a solucionarem o conflito entre os princípios da segurança c da cfetividade, no âmbito das tutclas urgentes (cognição sumária). Ao Icgislador coube a construção de todo um modelo teórico, composto pelos requisitos ordinários das medidas urgentes e pelas balizas legitimadoras da concessão destas. Scm embargo disso, o sistema oferece também algumas regras de calibração ou ajıstamento, por meio das quais é possível a resolução até mesmo dos casos considerados limítrofes.

5 - Conclusão

De acordo com CASTELLS, as últimas décadas do século XX presenciaram a consolidação de uma economia global, dotada da "capacidade de funcionar como uma unidade em tempo real, em escala planetária” A movimentação do capital ć administrada em mercados integrados por todo o mundo, funcionando em tempo real pela primeira vez na história. O tempo ainda é acelerado dentro das empresas: "formas flexíveis de gerenciamento, utilização contínua de capital fixo, desempenho intensificado de trabalhadores, alianças estratégicas e conexões interorganizacionais, tudo isso promove a compressão do tempo de cada operação e a aceleração da movimentação de recursos" ${ }^{2} 2.3$

Vivemos em uma sociedade urbana de massas, cujo anseio por bens materiais amplia-se constantemente. ${ }^{124}$ As exigências são cada vez mais diferenciadas, ${ }^{125}$

122 É decorrência lógica do "princípio da proporcionalidade: quanto mais grave for a interferência do provimento na esfera do peticionado, tanto mais rigoroso tem de ser o exame do direito e tanto mais severas hão de ser as exigências a impor a quem cabe tornar críveis as alegações" (BSAUR, Studien zum einstweiligen Rechtssschutz., 1967, trad. port. de A. E. Laux. Tutela juridlica mediante medidess cautelares, Porto Alegre, Sérgio Antônio Fabris, 1985, p. 51).

12.3 The rise of the network society', 1996, trad. port. de R. V. Majer, A sociedude em redle, $3^{2}$ ed., São Paulo, Paz e Terra, 2000, pp. 11 I e 464.

124 Cf. Ovido Baptista, Democracia moderna e processoo civil in Grinover, Dinamarco e Watanabe (org.), Participașão e processso, São Paulo, Revista dos Tribunais, 1988, p. 102.

125 MARINONı exemplifica com o crescimento exacerbado do setor terciário nas economias modernas, o que levou à multiplicação dos litígios envolvendo obrigações de fazer e não-fazer (Tutelas diferenciadas cit., p. 139). Esses conflitos, no entender de Barbosa Moreira, sāo alguns dos que põem à prova o sistema tradicional de proteção aos direitos, exigindo tutelas preventivas (Tutela sancionatória cit., p. 23). 
e seu atendimento demanda, com freqüência, uma velocidade nunca antes vista. ${ }^{16}$ Com esse contexto não se coaduna a morosidade tradicional do procedimento ordinário. $^{127}$

Nessa esteira, o problema da concessão de tutelas calcadas em cognição sumária vem assumindo enorme relevo. Presenciamos uma notável expansão do seu campo de aplicabilidade, frente às novas e peculiares necessidades da sociedade contemporânea. ${ }^{12 x}$

As implicações dessa evolução no campo do processo civil são imensas. ${ }^{12 y} \mathrm{O}$ tempo necessário a uma cognição exauriente e plena antes de qualquer provimento tornou-se um inconveniente, ante as novas necessidades das relações de dircito material. ${ }^{130}$ Daí a expansão do uso das tutclas urgentes, como técnica de sumarização apta a afastar o mal causado pela demora da prestação jurisdicional. ${ }^{131}$

A ampliação do recurso à cognição sumária atende à necessidade de adaptação dos procedimentos às vicissitudes dos direitos materiais, que é, de resto, a justificativa para a adoção das tutelas diferenciadas $\mathrm{em}$ geral.

Essa disseminação do uso das medidas de urgência torna essencial, ao jurista, o equacionamento do problema relativo ao binômio efetividade-segurança. Esse foi o propósito a que orientado o presente estudo. Sempre que se ache diante da possibilidade de concessão de uma medida dessa natureza, presente estará o conflito entre esses princípios, tão caros à ordem jurídica. ${ }^{132}$ A busca de mecanismos de soluçāo

126 Sobre o tema da velocidade das relações econômicas c suas implicaçōes no mundo do dircito v. MACEDO JÚNIOR, Sociologia jurídica e teoria do direito: a teoria relacional e a experiência contratual, tese de doutoramento, Universidade de São Paulo, 1997, esp. pp. 105-121).

127 “A redescoberta das tutelas sumárias (...), portanto, decorre da não adaptação de um sistema de distribuição de justiça à evolução da sociedade". (MARINONI, Tutelas diferenciadlas cit., p. 136).

128 "Seu âmbito de aplicação amplia-se constantemente: vai desde a proteção à honra e à personalidade, da proteção à empresa industrial e aos direitos referentes a bens imateriais, contra a concorrência desleal, desde a imposição de compromissos concernentes aos preços na distribuição de produtos do mercado, à obstação de mudança anticontratual de local de trabalho, à regulação de disputas políticas ou cientíícas, até a condenação a pagamentos provisionais no direito alimentar ou no da reparação do dano. Frente a este campo 'moderno' de aplicação da medida cautelar, as controvérsias, muitas vezes de fundo emocional, entre vizinhos e entre senhorios e inquilinos, passam para o segundo plano; a Economia e a Política descobriram a medida cautelar e a elegeram para um dos seus meios de combate" (BAUR, ob. cit., p. 13).

I29 Cf. Ovidio Baptista, Democracia moderna cit., p. 103.

130 Cf. Bedaque, Direito e processo cit., p. 113.

13. Cf. Bedaque, Tutela cautelar e tutela antecipada cit., p. 357.

132 Cf. Bedaque, ob. cil., p. 87. 
deve pautar as preocupações do operador do direito, atento que esteja às necessidades do sistema processual.

Essa tarefa, contudo, exige dele exacerbada prudência. ${ }^{133}$ Nunca é demais lembrar que do outro lado do conflito estão as garantias constitucionais da ampla defesa e do contraditório, indispensáveis para que o resultado do processo seja justo. A ânsia pela efetividade do acesso à justiça, tendente a constituir "procedimentos modernos e eficientes" traz sempre o perigo de que as demais garantias processuais sejam abandonadas..$^{134-135}$

Jamais se deve perder de vista que as modalidades de procedimento tradicionais, fundadas em cognição plena e exauriente, constituíram-se, ao longo de séculos de esforços, para prevenir abusos e arbitrariedades. Muito embora as vias ordinárias estejam bem longe do funcionamento ideal, especialmente face às novas premências da sociedade contemporânea, elas não deixam de desempenhar alguns importantes objetivos, que não podem ser esquecidos. ${ }^{136}$

Essas considerações devem informar a atividade do aplicador do direito. Em cada caso, a harmonização do conflito entre segurança e efetividade deve preservar, em grau máximo, todos os ditames do devido processo legal, em igualdade de condições a ambas as partes.

O que está em jogo não é só o interesse individual dos sujeitos processuais, apesar de ser ele o imediato e precípuo responsável pelos cuidados que permeiam a atividade jurisdicional. Ao lado disso, está o risco assumido pelo próprio sistema processual, que pode ver seu resultado largamente prejudicado. Quer porque inútil, quer porque injusto, o provimento estaria deixando de cumprir sua função instrumental, na medida em que inepto à consecução dos escopos do processo, sociais, políticos, e jurídico. ${ }^{137}$

I33 ARRUda Alvim faz o apelo para que o juiz atenda a esse "velho e nunca desgastado valor", que é "una das mais relevantes virtudes que pode ter um juiz, a inforınar a sua atividade jurisdicional". (Tutelı antecipatória cit., p. 23).

134 Cf. Cappelletti e Garth, Access to justice cit., p. 163.

135 BEDAQUE sintetiza o dilema: "adequar o sistema processual às necessidades do direito material, que requer soluções cada dia mais rápidas, sem que isso implique, todavia, sacrifício indevido da posição de um dos sujeitos parciais da relação processual". (Garantia da amplitude de produção probatória, in CRUz E TucCl (org.), Garantias constitucionais do processo civil, São Paulo, Revista dos Tribunais, 1999, p. 165).

1.36 Cf. Cappelletti e Garth, ob. cit., p. 164.

137 Sobre o tema, sempre, Dinamarco, A instrumentalidude cit., esp. pp. 149-223. 
Nunca se disse ser fácil a tarefa do juiz. "Nessas situações em vias de transformação, ou já transformadas, altera-se inevitável e profundamente a missão do juiz e conseqüentemente, os componentes, as peculiaridades e as estruturas de seu raciocínio. Além disso, nesse mundo globalizado é inevitável que o juiz se veja ao centro de muitos problemas novos e no ponto de encontro de tendências diferentes e conflitantes (...). Em uma palavra: o juiz não tem mais à sua disposição uma imagem simples e ordenada do mundo, à qual possa reportar-se como pano-de-fundo de seus raciocínios" 13 \%

Daí a importância, frise-se, do labor em torno do aprimoramento e sistematização das técnicas ${ }^{139}$ tendentes a solucionar a tensão do binômio efetividadesegurança, estabelecida em face da opção entre um procedimento de cognição sumária e outro de cognição exauriente. É o equacionamento dessas exigências opostas, ${ }^{141}$ facilitado em larga escala pela identificação dos limites dentro dos quais a tutela sumária deve ser concedida, que permitirá ser a tutela jurisdicional apta a cumprir fiel e integralmente todas as suas funções perante o direito, o Estado e a sociedade, cspecialmente seu primordial escopo perante esta última: climinar conflitos segundo os ditames da justiça.

São Paulo, maio de 2003. 39-40.

138 TaRUfro, Senso comum, experiência e ciência no raciocinio do juiz., Curitiba, IBEJ, 200I, pp.

139 Técnica processual essa bem entendida em seu sentido teleológico. É preciso sempre inanter acesa a "consciência de que ela está posta e há de ser empregada empiricamente a serviço dos diversos escopos predeterminados (do processo)" (Dinamarco, ob. cit., p. 226).

140 "Essas exigências opostas ligam-se a dois diferentes escopos do processo e o equilíbrio que se pretende constitui reflexo do entrosamento harmonioso que a ordem positiva há de dar à necessidade de atuar a vontade da lei e ao interesse social en pacificar, eliminando o conflito" (Dinamarco, ob. cit., p. 232). 
6- Bibliografia

Aragào, Egas Dirceu Moniz, Medidas cautelares inominadas, in Revista brasileira de direito processual, 57/33.

Armelin, Donaldo, Tutela jurisdicional diferenciada, in RePro 65/45.

Responsabilidade objetiva no código de processo civil, in J. R. Cruz c Tucci (org.), Processo civil - evolução - 20 anos de vigência, São Paulo, Saraiva, 1995.

Arruda Alvim, José Manuel, Tutela antecipatória-algumas noções-contrastes e coincidências em relação às medidas cautelares satisfativas, in T. A. A. W AmbIER (org.), Repertório de doutrina e jurisprudência sobre liminares, São Paulo, Revista dos Tribunais, 1995.

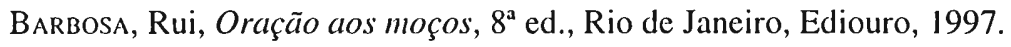

Barros, Suzana de Toledo, O princípio de proporcionalidade e o controle de constitucionalidade das leis restritivas de direitos fundamentais, Brasília, Brasília Jurídica, 1996.

Baur, Fritz, Studien zum einstweiligen Rechtsschutz, 1967, trad. port. de A. E. Laux, Tutela jurídica mediante medidas cautelares, Porto Alegre, Sérgio Antônio Fabris, 1985.

Bedaque, José Roberto dos Santos, Direito e processo (influência do direito material sobre o processo), São Paulo, Malheiros, 1995.

Garantia da amplitude de produção probatória, in J. R. Cruz e Tucci

(org.), Garantias constitucionais do processo civil, São Paulo, Revista dos Tribunais, 1999.

Tutela cautelar e tutela antecipada: tutelas sumárias e de urgência (tentativa de sistematização), São Paulo, Malheiros, 1998.

Bonavides, Paulo, Curso de direito constitucional, $4^{\mathrm{a}}$ ed., São Paulo, Malhciros, 1993.

Botelho de Mesquit^, José Ignácio, Limites ao poder do juiz nas cautelares antecipatórias, in Revista brasileira de direito processual, 56/45.

Calamandrei, Piero, Introduzione allo studio sistematico dei provedimenti cautelari, 1936, trad. port. de C. R. A. Bassi, Introdução ao estudo sistemático dos procedimentos cautelares, Campinas, Servanda, 2000.

Diritto processuale civile, trad. port. de L. Abezia e S. D. F. Barbery, Direito Processual Civil, v. III, Campinas, Bookseller, 1999.

Canotilno, José Joaquim Gomes, Direito constitucional, $5^{2}$ ed., Coimbra, Almedina, 1992.

Cappelletti, Mauro e GarTh, Bryant, Access to justice: the worldwide movement to make rights effective. A general report, 1978, Irad. port. de E. G. Northfleet, Acesso ì justiça, Porto Alegre, Sergio Antonio Fabris, 1988. 
Carnelutti, Francesco, Diritto e processo, Napoli, Morano, 1958.

CARrIÓ, Genaro R., Notas sobre Derecho y lenguaje, Buenos Aires, AbeledoPerrot, 1973.

CASTELlS, Manuel, The rise of the network society, 1996, trad. port. de R. V. Majer, A sociedade em rede, $3^{\mathrm{a}}$ ed., São Paulo, Paz e Terra, 2000.

Cintra, Antônio Carlos de Araújo, Grinover, Ada Pellegrini, e Dinamarco, Cândido Rangel, Teoria geral do processo, 15ª ed., São Paulo, Malheiros, 1999.

CRUz e Tucci, José Rogério, Ação monitória, São Paulo, Revista dos Tribunais, 1995.

Garantia da prestação jurisdicional sem dilações indevidas como corolário do devido processo legal, in Repro 66/72.

Dinamarco, Cândido Rangel, $A$ instrumentalidade do processo, $9^{a}$ ed., São Paulo, Malheiros, 2001.

A reforma da reforma, São Paulo, Malheiros, 2002.

A reforma do código de processo civil, $3^{\mathrm{a}}$ ed. São Paulo, Malheiros,

1996.

Malheiros, 2000.

Fundamentos do processo civil moderno, $3^{\mathrm{a}}$ ed., t. I, São Paulo,

Instituições de direito processual civil, São Paulo, Malheiros, 2001. $O$ regime jurídico das medidas urgentes, in $R F$ 356/29.

, CinTRA, Antônio Carlos de Araújo, e Grinover, Ada Pellegrini, Teoria geral do processo, $15^{\mathrm{a}}$ ed., São Paulo, Malheiros, 1999.

Dworkin, Ronald, Taking rights seriously, 1978, trad. port. de N. Boeira, Levando os direitos a sério, São Paulo, Martins Fontes, 2002.

Ferraz JúnIOR, Tércio Sampaio, Introdução ao estudo do direito - técnica, decisão, dominação, São Paulo, Atlas, 1994.

GARTH, Bryant e CAPPELLETTI, Mauro, Access to justice: the worldwide movement to make rights effective. A general report, 1978, trad. port. de E. G. Northfleet, Acesso à justiça, Porto Alegre, Sergio Antonio Fabris, 1988.

Grau, Eros Roberto, A ordem econômica na constituição de 1988, $6^{a}$ ed., São Paulo, Malheiros, 2001.

GrINOVER, Ada Pellegrini, O princípio da ampla defesa no processo civil, penal e administrativo, in O processo em sua unidade - II, Rio de Janeiro, Forense, 1984.

Teoria geral do processo, $15^{\text {a }}$ ed., São Paulo, Malheiros, 1999.

LACERDA, Galeno, Comentários ao código de processo civil, $4^{\mathrm{a}}$ ed., v. VIII, t. I, Rio de Janeiro, Forense, 1992.

LARENZ, Karl, Methodenlehre der rechtswissenschaft, 1991, trad. port. de J. Lamego, Metodologia da ciência do direito, $3^{\mathrm{a}}$ ed., Lisboa, Calouste Gulbenkian, 1997. 
Liebman, Enrico Tullio, Unità del procedimento cautelare, in Problemi del processo civile, Milano, Morano, 1962.

Lucon, Paulo Henrique dos Santos, Eficácia das decisões e execução provisória, São Paulo, Revista dos Tribunais, 2000.

MACEDO JúNIOR, Ronaldo Porto, Sociologia jurídica e teoria do direito: a teoria relacional e a experiência contratual, tese de doutoramento, Universidade de São Paulo, 1997.

Marcato, Antonio Carlos, O processo monitório brasileiro, São Paulo, Malheiros, 1998.

MARINONI, Luiz Guilherme, A antecipação da tutela na reforma do processo civil, São Paulo, Malheiros, 1995.

Novidades sobre a tutela antecipatória, in Repro 69/105.

Observações sobre a tutela antecipatória, in Repro 79/104.

Tutela cautelar e tutela antecipatória, São Paulo, Revista dos

Tribunais, 1992.

Tutelas diferenciadas e realidade social, in H. W. Rodrigues (org.), Lições alternativas de direito processual, São Paulo, Acadêmica, 1995.

Moreira, José Carlos Barbosa, A garantia do contraditório na atividade de instrução, in RePro 35/231.

Notas sobre o problema da "efetividade" do processo, in A. P. Grinover et al., Estudos de direito processual em homenagem a José Frederico Marques no seu $70^{\circ}$ aniversário, São Paulo, Saraiva, 1982.

Tutela sancionatória e tutela preventiva, in Temas de direito processual, $2^{\mathrm{a}}$ série, $2^{\mathrm{a}}$ ed., São Paulo, Saraiva, 1988.

Os princípios do direito processual civil na constituição de 1988, in J. Tubenchlak e R. Bustamante (org.), Livro de estudos jurídicos, v. 4, Rio de Janeiro, Instituto de Estudos Jurídicos, 1992.

NERY JÚNIOR, Nelson, Princípios do processo civil na constituição federal, $5^{\mathrm{a}}$ ed., São Paulo, Revista dos Tribunais, 1999.

OliveIRA, Carlos Alberto Álvaro de, Efetividade e processo cautelar, in Ajuris $61 / 175$.

Janeiro, Forense, 1988.

Comentários ao código de processo civil, $3^{\mathrm{a}}$ ed., v. VIII, t. II, Rio de

Garantia do contraditório, in J. R. Cruz e Tucci (org.), Garantias constitucionais do processo civil, São Paulo, Revista dos Tribunais, 1999.

Portanova, Rui, Princípios do processo civil, Porto Alegre, Livraria do Advogado, 1995.

Proto PISAnI, Andréa, Sulla tutela giurisdizionale differenziata, in Rivista di diritto processuale, n. 4, 1979. 
Reale, Miguel, Filosofia do direito, v. I , $3^{\text {a }}$ ed., São Paulo, Saraiva, 1962.

SiCHES, Luis Recaséns, Nueva filosofia de la interpretación del derecho, 2 ed., México, Porrúa, 1973.

SILva, José Afonso da, Curso de direito constitucional positivo, $18^{\mathrm{a}}$ ed., São Paulo, Malheiros, 2000.

Silva, Ovídio Araujo Baptista da, A ação cautelar inominada no direito brasileiro, Rio de Janeiro, Forense, 1979.

Do processo cautelar, Rio de Janeiro, Forense, 2001.

A "plenitude de defesa" no processo civil, in S. de F. Teixeira (org.), As garantias do cidadão na justiça, São Paulo, Saraiva, 1993.

Democracia moderna e processo civil, in A. P. Grinover, C. R. Dinamarco e K. Watanabe (org.), Participação e processo, São Paulo, Revista dos Tribunais, 1988.

Souza, Carlos Aurélio Mota de, Segurança jurídica e jurisprudência - um enfoque filosófico-jurídico, São Paulo, Letras Trabalhistas, 1996.

TARUfFo, Michele, Senso comum, experiência e ciência no raciocínio do juiz, Curitiba, IBEJ, 2001.

ThEODORO JúNIOR, Humberto, O processo civil brasileiro no limiar do novo século, Rio de Janeiro, Forense, 1999.

Tommaseo, Ferrucio, I provvedimenti d'urgenza - strutura e limiti della tutela anticipatoria, Padova, Cedam, 1983.

Warat, Luis Alberto, $O$ direito e sua linguagem, $2^{\mathrm{a}}$ ed., Porto Alegre, Sergio Antonio Fabris, 1995.

Watanabe, Kazuo, Da cognição no processo civil, $2^{a}$ ed., Campinas, Bookseller, 2000 .

Tutela antecipada e específica e obrigações de fazer e não fazer, in

Revista especial do Tribunal Regional Federal da 3“ Região, v. 1, 1997.

ZaVASKı, Teori Albino, Antecipação da tutela, São Paulo, Saraiva, 2000.

Antecipação de tutela e colisão de direitos fundamentais, in T. A. A.

WAMBIER (org.), Repertório de doutrina e jurisprudência sobre liminares, São Paulo,

Revista dos Tribunais, 1995. 